\title{
Effect of Micro Algae on Rhizoctonia solani and Botanicals on Curvularia spp. of Finger Millet (Eleusine coracana L.)
}

\author{
Sandra Saichandrababu Naidu* and Sobita Simon
}

Department of Plant Pathology, Sam Higginbottom University of Agriculture, Technology and Sciences, Prayagraj-211007, (U.P), India

*Corresponding author

\section{A B S T R A C T}

\section{Keywords}

Curvularia spp, Finger millet, Microalage, Rhizoctonia solani

Article Info

\section{Accepted:}

17 January 2021

Available Online:

10 February 2021
Finger millet (Eleusine coracana L.) is a member of eight minor millets group, constitutes about $81 \%$ of minor millets produced in India. The crop is affected by sheath blight caused by Rhizoctonia solani and leaf spot caused by Curvularia spp. Different doses of microalgae were applied @ (1.5, 2.5, 3.5, 4.5 and $5.5 \mathrm{~kg} / \mathrm{acre})$ with irrigation at critical growth stages of crop (Vegetative phase, Flowering phase and Maturity phase) and observations were recorded on plant growth parameters and per cent disease incidence of $R$. solaniin leaf sheath. In-vitro effect of different botanicals (Trumphet leaf extract, Trumphet flower extract, Bryophyllum leaf extract, Ashok leaf extract and Moringa leaf extract) at different concentrations (5 and 10\%) were screened on radial growth of Curvularia spp. which was isolated from the leaf of Finger millet. Results shows that, the application of microalgae of all the doses significantly reduced the per cent disease incidence of $R$. solani as compared with control at 60 and 90 DAT of microalgae. In-vitro effect of the botanicals on radial growth of Curvularia spp. was recorded after $96 \mathrm{hrs}$ of incubation and the result showed that, among the treatments, Ashoka leaf extract at 5\% and $10 \%$ significantly inhibited the percentage mycelial growth with $60.60 \%$ and $81.96 \%$ which was significant over other botanicals. All the botanical extracts significantly reduced the radial growth of Curvularia spp. from control.

\section{Introduction}

In India, finger millet is cultivated over an area of 1.19 million hectares with a production of 1.98 million ton giving an average productivity of $16.61 \mathrm{q} / \mathrm{ha}$. Karnataka accounts for 56.21 and $59.52 \%$ of area and production of finger millet followed by Tamil Nadu $(9.94 \%$ and $18.27 \%)$, Uttarakhand (9.40\% and $7.76 \%)$ and Maharashtra $(10.56 \%$ and $7.16 \%$ ), respectively (Sakamma et al., 2018).

Finger millet crop is affected by several biotic stresses of which diseases like Finger millet blast, Sheath blight (Rhizoctonia solani) and Curvularia leaf spot cause qualitative and quantitative reduction in yield. Sheath blight of little millet incited by Rhizoctonia solani (Kuhn.) is one of the emerging malady in 
successful cultivation of little millet Akhtar et al. (2009) reported wide spread occurrence of sheath blight of maize caused by Rhizoctonia solani in Jharkhand with disease severity ranging from 30.30 to $80.46 \%$. Anonymous (2013) reported sheath blight incidence in little millet entries at Rewa (2.3 to 40.4\%), Ranchi (0.0 to $34.5 \%)$ and Vizianagaram (0.0 to $60.0 \%)$.

The microalgae filtrate exhibited an inhibitory activity against the fungal tested organisms. Significant stimulating effects were produced on the tomato seeds which previously soaked in $C$. minutus culture filtrate, in retarding the Phythium spp. symptoms (Ibrahim et al., 2008). Extracts from sea weeds (microalgae) sprayed on plants have been reported to reduce the incidence of Botrytis cinera (gray mold) on strawberries, Erysiphe polygoni (powdery mildew) on turnips, and dampingoff of tomato seedlings (Kulik, 1995). The Cyanobacterial and algal extracts, the algal extracts used in the study showed higher efficiency towards antimicrobial activity. Microalgae are able to produce biomass that might be used in different sectors such as: Fuel, food, animal feed, pharmaceutical and crop productions. Regarding crop productions, microalgae contain high levels of macronutrients and micronutrients essential for an optimal crop growth and development.

Plants produce numerous secondary plant metabolites that are insignificant for growth and developmental processes (Rosenthal et al., 1991) act against microbial pathogens on the basis of their toxic nature (Schafer et al., 2009). Exploration of plant-based pesticides to control post-harvest losses is one of the feasible methods, lead to ecofriendly use of natural products, act as rich source of natural compounds exhibiting many fungicidal and other properties with least side effects. Antifungal activity of plant extracts may be more effective than some commercial synthetic fungicides natural occurring substances in plants with anti-microbic properties (Tamuli, 2014). Therefore, it has become necessary to adopt ecofriendly management practices for plant health management and better yield. In the present review different in-vitro studies are discussed to control plant pathogens.

Considering the above mentioned facts, a study entitled "Effect of microalgae on Rhizoctonia solani and botanicals on Curvularia spp. of Finger millet (Eleusine coracana $\mathrm{L}$.

\section{Materials and Methods}

\section{Isolation and Identification of Rhizactonia} solani from leaf sheath of finger millet

\section{Isolation of $\boldsymbol{R}$. solani}

Infected leaves and sheath of Finger millet were washed first in water and thenin mercuric chloride $\left(\mathrm{HgCl}_{2}\right)$ to disinfect the surface of leaves. After that, leaves were cut into small pieces and transferred to the Petri plates containing PDA (four pieces per plate) and plates were incubated at $25 \pm 2^{0} \mathrm{C}$ for $3-4$ days in inverted position. After 3-4 days, colonies of the fungus appeared and slides were prepared (Tuite, 1969). The fungus was purified through hyphal tip/single sclerotial method (Rangaswami and Mahadevan, 2004).

\section{Identification of $\boldsymbol{R}$. solani}

The pathogen (R. solani) isolated in PDA was produced white mycelial growth at first but later on it turned into light cream color to yellowish cream color. The mycelium was septate and hyaline. Further the mycelium aggregated and formed the sclerotia with respected color and pattern of distribution (Butler, 1957). 
Isolation and identification of Curvularia spp. from leaf spot of finger millet

\section{Isolation of Curvularia spp}

The infected leaves was brought and cut into small pieces, surface sterilized with mercuric chloride for 15-30 seconds, rinsed with three changes of sterile distilled water to remove disinfectant and bottled dry. The sterilized pieces were plated on Potato Dextrose Agar (PDA) medium in petri plates under aseptic conditions and incubated at $25^{\circ} \mathrm{C}$ for 2 weeks. For obtaining sufficient quantity of inoculums, pure cultures was obtained by sub culturing.

\section{Identification of Curvularia spp}

The pathogen (Curvularia spp.) isolated in PDA was produced black color mycelial growth. The microscopic structure of conidia observed was dark/pale brown conidia with $3 / 4$ septa and the conidia was curved and prominence of geniculate growth pattern was observed. The central cell is typically darker and enlarged compared to the end cells in the conidium. The swelling of the central cell usually gives the conidium a curved appearance (Keys identified based on literature of (Benoit and Mathur, 1970).

\section{Preparation of plant extracts}

The freshly selected Trumpet leaves, Trumpet flowers, Bryophyllum leaves, Ashoka leaves and Moringa leaves were collected and washed thoroughly with clean water and dried. Plant leaves were grounded in a pestle and mortar by adding same proportion of sterilized distilled water in weight by volume method $(1: 1 \mathrm{w} / \mathrm{v})$. The extract was filtered through double layered muslin cloth and the filtrate were added to PDA media according to the required concentrations for poison food technique (Gurjar et al., 2012).

\section{Poison food technique}

Five-millimeter diameter disc of Curvularia spp. was kept at the centre of each Petri plate containing botanicals of required concentration dissolved in PDA. Three replications were maintained. The plates were incubated at $27 \pm 1^{\circ} \mathrm{C}$ for ten days and colony diameter was recorded. Per cent inhibition of mycelial growth was calculated by using the formula given by Vincent (1947):

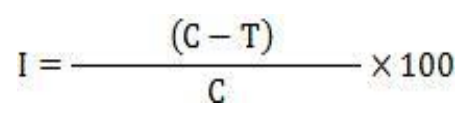

Where

$\mathrm{C}=$ Mycelium weight in control.

$\mathrm{T}=$ Mycelium weight in treatment.

\section{Results and Discussion}

\section{In vitro evaluation ofbotanicals against Curvularia spp}

The results presented in table 1 and depicted in plate no (1) and figure (1) revealed that all the botanicals tested were significantly effective in inhibiting the growth of pathogen over control. The results indicated that increase in percent inhibition was variably in proportion to increase in the concentration ( 5 and $10 \%$ ) of the plant extracts. Among different plant extracts tested Ashoka leaves extract at 5 and $10 \%$ showed maximum inhibition followed by Bryophyllum leaf extract, Trumpet flower extract, Moringa leaf extract and minimum inhibition was showed inTrumpet leaf extract.

However, at 5\% concentration, all the treatments were significant over control. Among the treatments $\left(\mathrm{T}_{4}\right.$ and $\left.\mathrm{T}_{2}\right),\left(\mathrm{T}_{2}\right.$ and $\left.\mathrm{T}_{3}\right)$ and $\left(T_{3}\right.$ and $\left.T_{5}\right)$ were found non-significant to each other.

At $10 \%$ concentration, all the treatments were significant over control. Among the 
treatments, $\left(\mathrm{T}_{3}\right.$ and $\left.\mathrm{T}_{2}\right),\left(\mathrm{T}_{2}\right.$ and $\left.\mathrm{T}_{5}\right)$ and $\left(\mathrm{T}_{5}\right.$ and $\mathrm{T}_{1}$ ) were non significant and statistically at par with each other.

\section{Effect of Micro alage at different doses on $\boldsymbol{R}$. solani disease incidence of Finger millet at 60 and 90 DAT}

Perusal of data in table 2 (Fig 2) reveals that Microalgae $5.5 \mathrm{~kg} /$ acre at 60 and 90 DAT has significantly reduced the per cent disease incidence $(20.11 \%$ and $26.13 \%$ ) as compared with Microalgae $4.5 \mathrm{~kg} / \mathrm{acre}(22.65 \%$ and $29.50 \%$ respectively), Microalgae $3.5 \mathrm{~kg} /$ acre $(24.41 \%$ and $34.71 \%$ respectively), Microalgae $2.5 \mathrm{~kg} /$ acre $(26.10 \%$ and $39.07 \%$ respectively), Microalgae $1.5 \mathrm{~kg} /$ acre $(27.40 \%$ and $41.60 \%$ respectively), and control (28.70\% and $47.72 \%$ respectively).

However, at 60 DAT the treatments $\left(\mathrm{T}_{2}\right.$ and $\mathrm{T}_{1}$ ) were found non-significant and statistically at par with each other, at 90 DAT all the treatments were found significant over control.

\section{Plant height (cm)}

Perusal of data in table 3 (Fig 3) reveals that Microalgae $5.5 \mathrm{~kg} /$ acre at 30,60 and 90 DAT has significantly increased the plant height (25.90,77.71 and 112.80), as compared with other treatments i.e., Microalgae $4.5 \mathrm{~kg} /$ acre (23.89,75.33 and 109.66), Microalgae $3.5 \mathrm{~kg} / \mathrm{acre} \quad(23.11,72.67$ and 103.16), Microalgae $2.5 \mathrm{~kg} /$ acre $\quad(21.34,70.51$ and 101.33), Microalgae 1.5kg/acre (19.67, 68.91 and 99.10), and untreated check (17.30, 66.57 and 91.54).

However, at 30 DAT the treatments $\left(\mathrm{T}_{3}\right.$ and $\mathrm{T}_{4}$ ) were found non-significant and statistically at par with each other, At 60 and 90 DAT all the treatments were found significant over control.

\section{Yield components of finger millet}

\section{Number of Spikelets}

Data recorded in Table 4 showed that, among all the treatments, Number of spikelets were significantly increased in Microalgae @ 5.5kg/acre (6.67) followed by Microalgae @ 4.5kg/acre (6.33), Microalgae @3.5kg/acre (6.0), Microalgae @2.5kg/acre (5.67) and Microalgae @1.5kg/acre (5.33) in comparison of control (4.67). However, all the treatments were significant over control. Among the treatments $\left(\mathrm{T}_{0}, \mathrm{~T}_{1}, \mathrm{~T}_{2}, \mathrm{~T}_{3}\right.$ and $\left.\mathrm{T}_{4}\right),\left(\mathrm{T}_{1}, \mathrm{~T}_{2}, \mathrm{~T}_{3}\right.$, and $\left.\mathrm{T}_{5}\right),\left(\mathrm{T}_{2}, \mathrm{~T}_{3}\right.$, and $\left.\mathrm{T}_{4}\right),\left(\mathrm{T}_{3}, \mathrm{~T}_{4}\right.$ and $\left.\mathrm{T}_{5}\right)$ and $\left(\mathrm{T}_{4}\right.$ and $\mathrm{T}_{5}$ ) were found non-significant to each other.

\section{Length of spikelets}

Data recorded in Table 4 showed that, among all the treatments, Length of Spikelets $(\mathrm{cm})$ were significantly increased in Microalgae @ $5.5 \mathrm{~kg} /$ acre (11.57) followed by Microalgae @ 4.5kg/acre (9.93), Microalgae @ 3.5kg/acre (9.47), Microalgae @2.5kg/acre (8.40) and Microalgae @1.5kg/acre (8.00) in comparison of control (7.30). However, all the treatments were significant over control. Among the treatment $\left(\mathrm{T}_{0}\right.$ and $\left.\mathrm{T}_{1}\right),\left(\mathrm{T}_{1}\right.$ and $\left.\mathrm{T}_{2}\right)$ and $\left(\mathrm{T}_{3}\right.$ and $\mathrm{T}_{4}$ ) were found non-significant to each other.

\section{0 grain weight}

Data recorded in Table 4 showed that, among all the treatments, 1000 grain weight (gm) were significantly increased in @ Microalgae @ $5.5 \mathrm{~kg} /$ acre (3.65) followed by Microalgae @ 4.5kg/acre (3.41), Microalgae @ 3.5kg/acre (3.23), Microalgae @2.5kg/acre (3.02) and Microalgae @1.5kg/acre (2.82) in comparison of control (2.60). However, all the treatments were significant over control. 
Table.1 In vitro effect of botanicals on radial growth (mm) of Curvularia spp. at different concentrations

\begin{tabular}{|c|c|c|c|c|c|}
\hline \multirow{2}{*}{$\begin{array}{c}\text { Treatment } \\
\text { no. }\end{array}$} & \multirow[t]{2}{*}{ Treatment name } & \multicolumn{4}{|c|}{ Radial growth $(\mathrm{mm})$ of the three replicates mean after 96hours } \\
\hline & & $5 \%$ conc. & Inhibition \% & $10 \%$ conc. & Inhibition \% \\
\hline $\mathbf{T}_{\mathbf{0}}$ & Control & 85.00 & 0 & 85.00 & 0 \\
\hline $\mathbf{T}_{1}$ & Trumpet Leaf extract & 50.66 & 23.24 & $32.66^{\mathrm{c}}$ & 61.57 \\
\hline $\mathbf{T}_{2}$ & $\begin{array}{c}\text { Trumpet flower } \\
\text { extract }\end{array}$ & $30.50^{\mathrm{ab}}$ & 53.78 & $26.66^{\mathrm{ab}}$ & 68.63 \\
\hline $\mathbf{T}_{\mathbf{3}}$ & $\begin{array}{c}\text { Bryophyllum leaf } \\
\text { extract }\end{array}$ & $32.66^{\mathrm{bc}}$ & 50.51 & $25.00^{\mathrm{a}}$ & 70.58 \\
\hline $\mathbf{T}_{4}$ & Ashoka leaf extract & $26.00^{\mathrm{a}}$ & 60.60 & 15.33 & 81.96 \\
\hline $\mathbf{T}_{5}$ & Moringa leaf extract & $36.66^{\mathrm{c}}$ & 44.45 & $31.00^{b c}$ & 63.52 \\
\hline & $\operatorname{SEd}( \pm)$ & 2.45 & - & 2.30 & - \\
\hline & CD (at 5\%) & 5.35 & - & 5.03 & - \\
\hline
\end{tabular}

Means with similar letters represents non-significant to each other at $5 \%$ level.

Table.2 Effect of Microalgae on Disease incidence (\%) at different DAI Sheath blight in Fingermillet

\begin{tabular}{|l|c|c|}
\multirow{2}{*}{ Treatment details } & \multicolumn{2}{|c|}{ Disease incidence(\%) } \\
\cline { 2 - 3 } & 60DAT & 60DAT \\
\hline $\mathrm{T}_{0}$ Control & $\mathbf{2 8 . 7 0}$ & $\mathbf{4 7 . 7 2}$ \\
\hline $\mathrm{T}_{1}$ (Microalgae $1.5 \mathrm{~kg} /$ acre) & $\mathbf{2 7 . 4 0}$ & $\mathbf{4 1 . 6 0}$ \\
\hline $\mathrm{T}_{2}$ (Microalgae $2.5 \mathrm{~kg} /$ acre) & $\mathbf{2 6 . 1 0 ^ { \mathbf { a } }}$ & $\mathbf{3 9 . 0 7}$ \\
\hline $\mathrm{T}_{3}$ (Microalgae $3.5 \mathrm{~kg} /$ acre) & $\mathbf{2 4 . 4 1}$ & $\mathbf{3 4 . 7 1}$ \\
\hline $\mathrm{T}_{4}$ (Microalgae $4.5 \mathrm{~kg} /$ acre) & $\mathbf{2 2 . 6 5}$ & $\mathbf{2 9 . 5 0}$ \\
\hline $\mathrm{T}_{5}$ (Microalgae $5.5 \mathrm{~kg} /$ acre) & $\mathbf{2 0 . 1 1}$ & $\mathbf{2 6 . 1 3}$ \\
\hline $\mathrm{SEd}( \pm)$ & $\mathbf{0 . 5 9}$ & $\mathbf{0 . 6 7}$ \\
\hline $\mathrm{CD}(5 \%)$ & $\mathbf{1 . 3 2}$ & $\mathbf{1 . 5 0}$ \\
\hline
\end{tabular}

Means with similar letters represents non-significant to each other at 5\% level *Mean of Three Replications.

Table.3 Effect of Microalgae on plant height $(\mathrm{cm})$ of Finger millet at 30, 60 and 90 DAT

\begin{tabular}{|c|c|c|c|}
\hline \multirow{2}{*}{ Treatment Details } & \multicolumn{3}{|c|}{ Mean of three replicas } \\
\cline { 2 - 4 } & $\begin{array}{c}\mathbf{3 0} \\
\text { DAT }\end{array}$ & $\begin{array}{c}\mathbf{6 0} \\
\text { DAT }\end{array}$ & $\begin{array}{c}\mathbf{9 0} \\
\text { DAT }\end{array}$ \\
\hline $\mathbf{T}_{\mathbf{0}}$ & 17.30 & 66.57 & 91.54 \\
\hline $\mathbf{T}_{\mathbf{1}}$ & 19.67 & 68.91 & 99.10 \\
\hline $\mathbf{T}_{\mathbf{2}}$ & 21.34 & 70.51 & 101.33 \\
\hline $\mathbf{T}_{\mathbf{3}}$ & $23.11^{\mathrm{a}}$ & 72.67 & 103.16 \\
\hline $\mathbf{T}_{\mathbf{4}}$ & $23.89^{\mathrm{a}}$ & 75.33 & 109.66 \\
\hline $\mathbf{T}_{\mathbf{5}}$ & 25.90 & 77.71 & 112.80 \\
\hline $\mathrm{SEd}( \pm)$ & 0.55 & 0.60 & 0.52 \\
\hline $\mathrm{CD}(5 \%)$ & 1.23 & 1.34 & 1.15 \\
\hline
\end{tabular}

Means with similar letters represents non-significant to each other at $5 \%$ level

*Mean of Three Replications 
Table.4 Effect of Microalgae on Yield parameters of Finger millet

\begin{tabular}{|c|c|c|c|c|}
\hline \multirow[b]{2}{*}{$\begin{array}{l}\text { Treatment } \\
\text { details }\end{array}$} & \multicolumn{3}{|c|}{ Yield components } & \multirow{2}{*}{$\begin{array}{l}\text { Grain } \quad \text { yield } \\
(\mathrm{q} / \mathrm{ha})\end{array}$} \\
\hline & No. of Spikelets & $\begin{array}{l}\text { Length of } \\
\text { Spikelets }\end{array}$ & 1000 grain weight & \\
\hline $\mathrm{T}_{0}$ & $4.67^{\mathrm{a}}$ & $7.30^{\mathrm{a}}$ & 2.60 & 19.32 \\
\hline $\mathrm{T}_{1}$ & $5.33^{\mathrm{ab}}$ & $8.00_{\mathrm{ab}}$ & 2.82 & 21.70 \\
\hline $\mathrm{T}_{2}$ & $5.67^{\mathrm{abc}}$ & $8.40^{\mathrm{b}}$ & 3.02 & 22.90 \\
\hline $\mathrm{T}_{3}$ & $6.00^{\mathrm{abc}}$ & $9.47^{c}$ & 3.23 & 23.50 \\
\hline $\mathrm{T}_{4}$ & $6.33^{\mathrm{abc}}$ & $9.93^{c}$ & 3.41 & 24.63 \\
\hline $\mathrm{T}_{5}$ & $6.67^{\mathrm{bc}}$ & 11.57 & 3.65 & 25.42 \\
\hline $\operatorname{SEd}( \pm)$ & 0.78 & 0.32 & 0.04 & 0.25 \\
\hline $\mathrm{CD}(5 \%)$ & 1.75 & 0.72 & 0.09 & 0.57 \\
\hline
\end{tabular}

Means with similar letters represents non-significant to each other at $5 \%$ level

*Mean of Three Replications.

Mycelium of R.solaniPure culture of R.solani

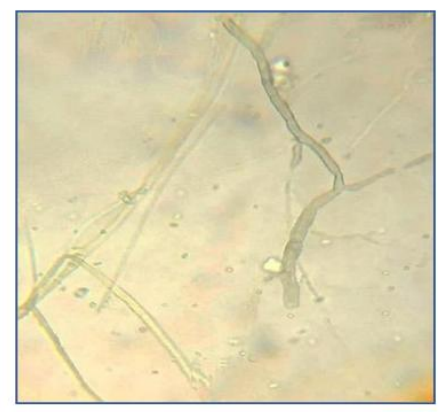

Conidia of Curvularia spp (under 40x)

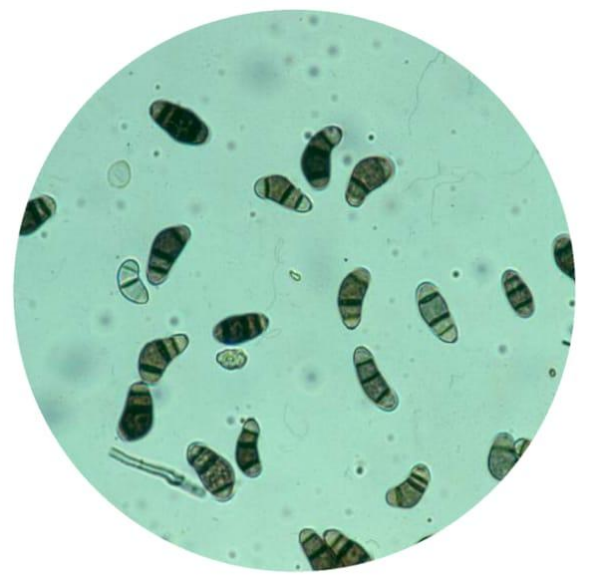

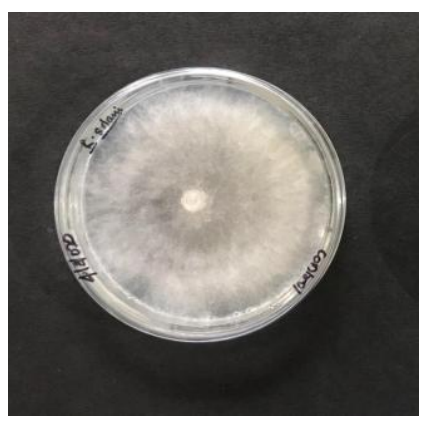

Pure culture of Curvularia spp

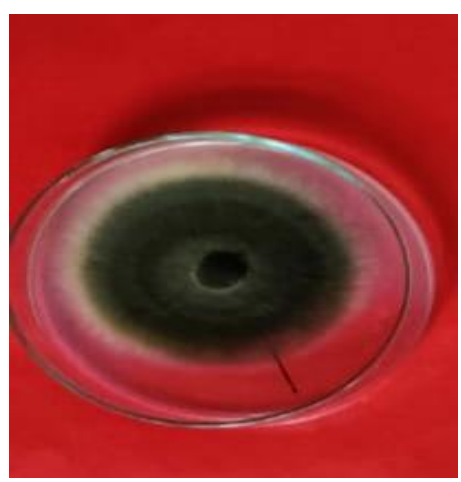


Plate.1 Radial growth (mm) of Curvularia spp.at 5\% and $10 \%$ concentration

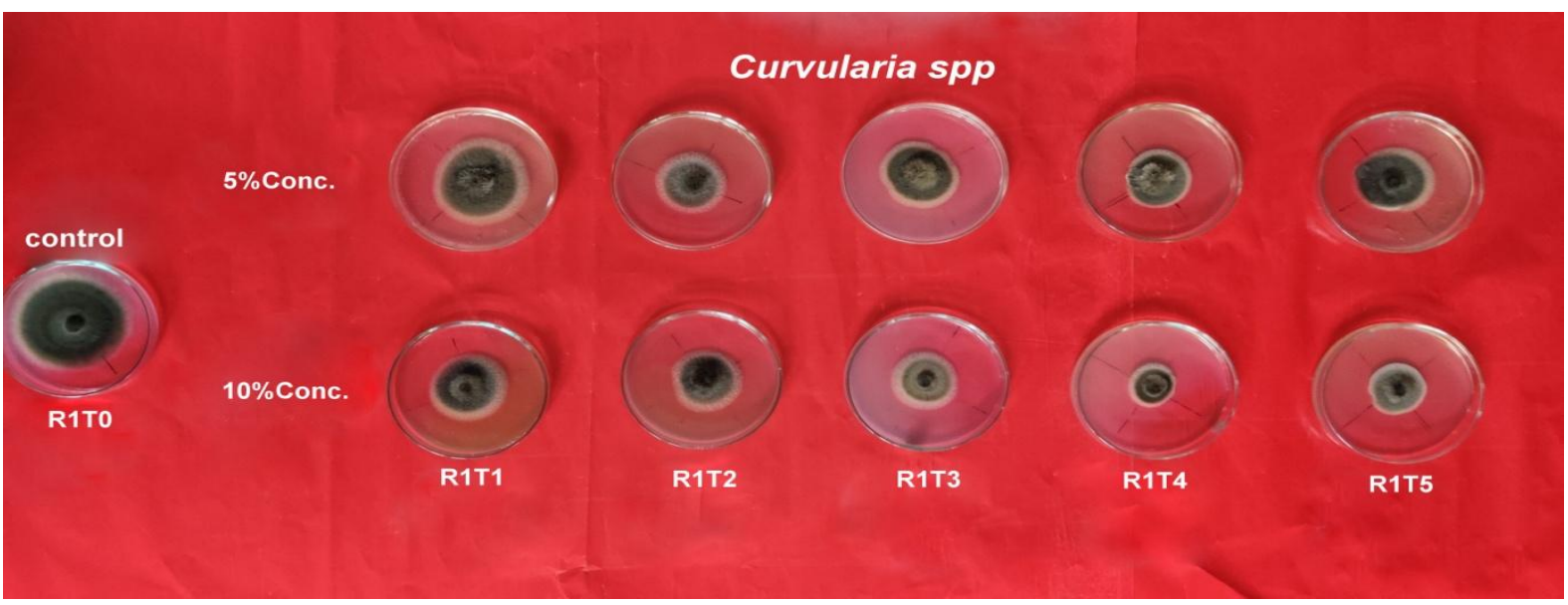

Fig.1 In vitro effect of botanicals on radial growth (mm) of Curvularia spp. at different concentrations

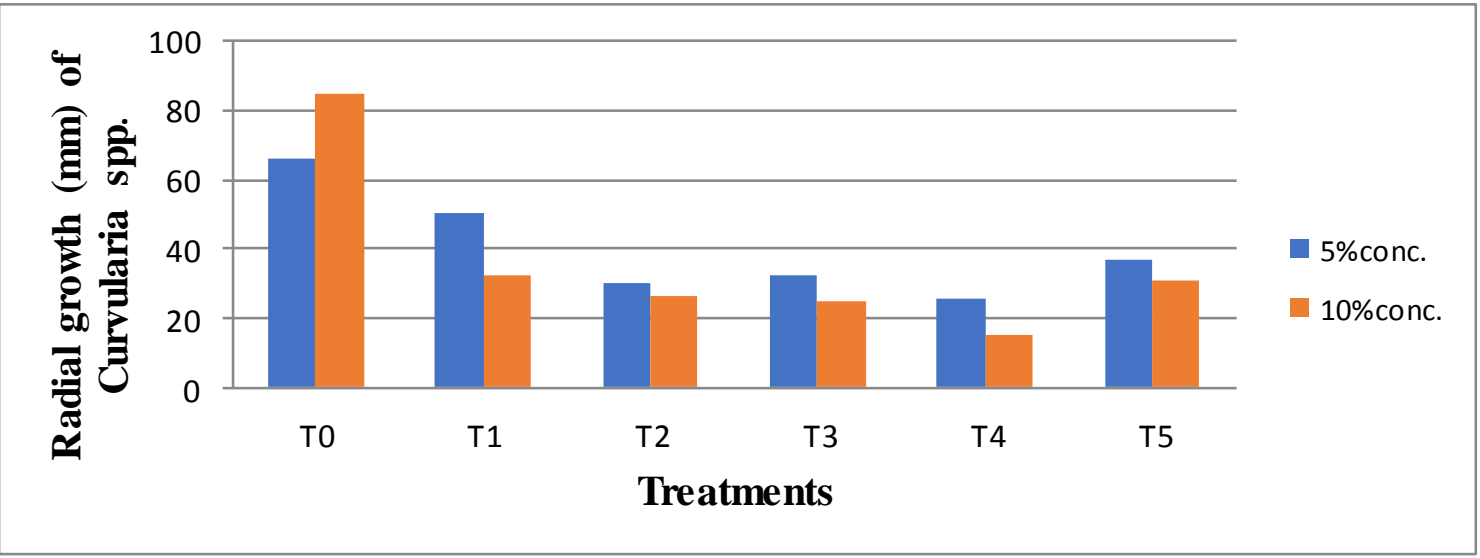

Fig.2 Effect of Microalgae on Disease incidence (\%) at different DAI Sheath blight in fingermillet

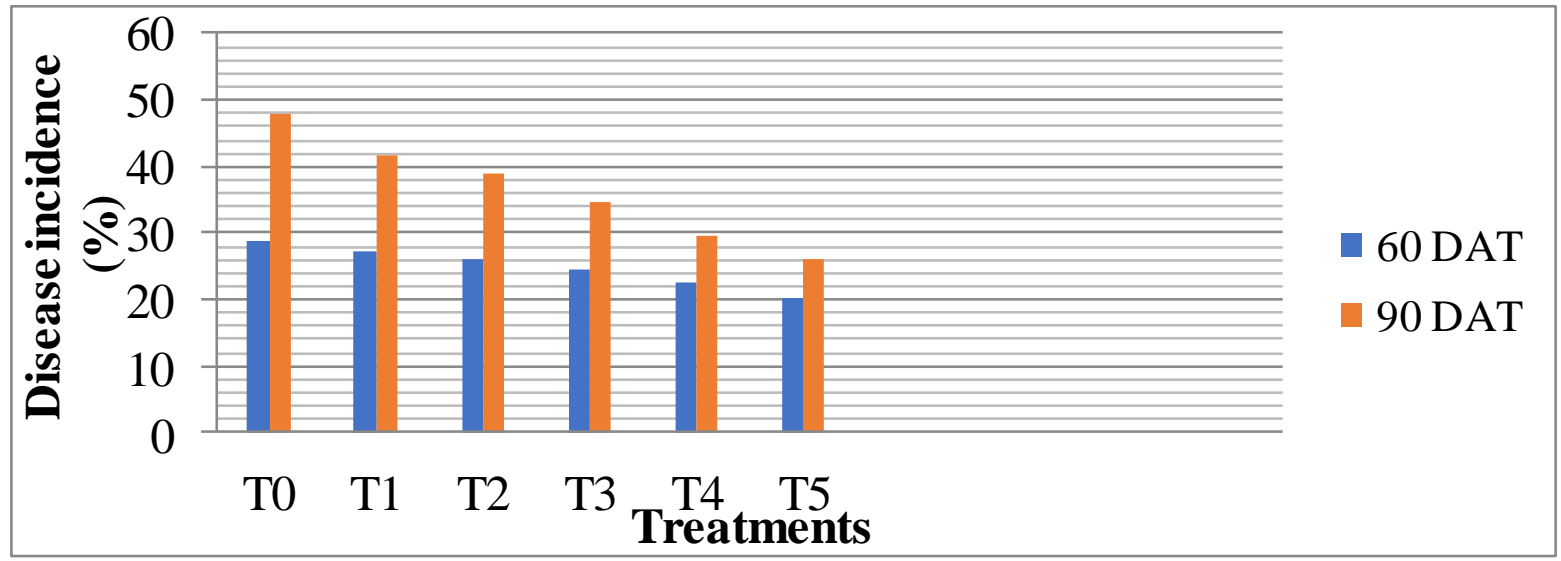


Fig.3 Effect of Microalgae on plant height $(\mathrm{cm})$ of Finger millet at 30, 60 and 90 DAT

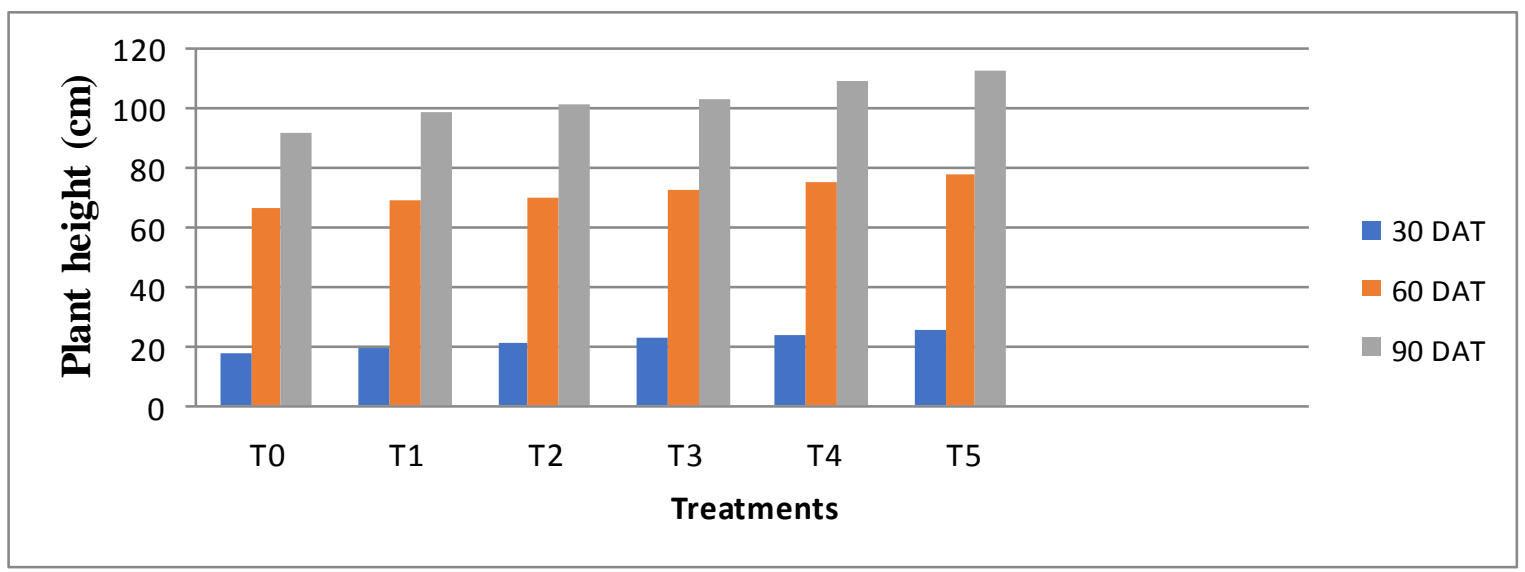

Fig.4 Effect of Microalgae on Yield parameters of Finger millet
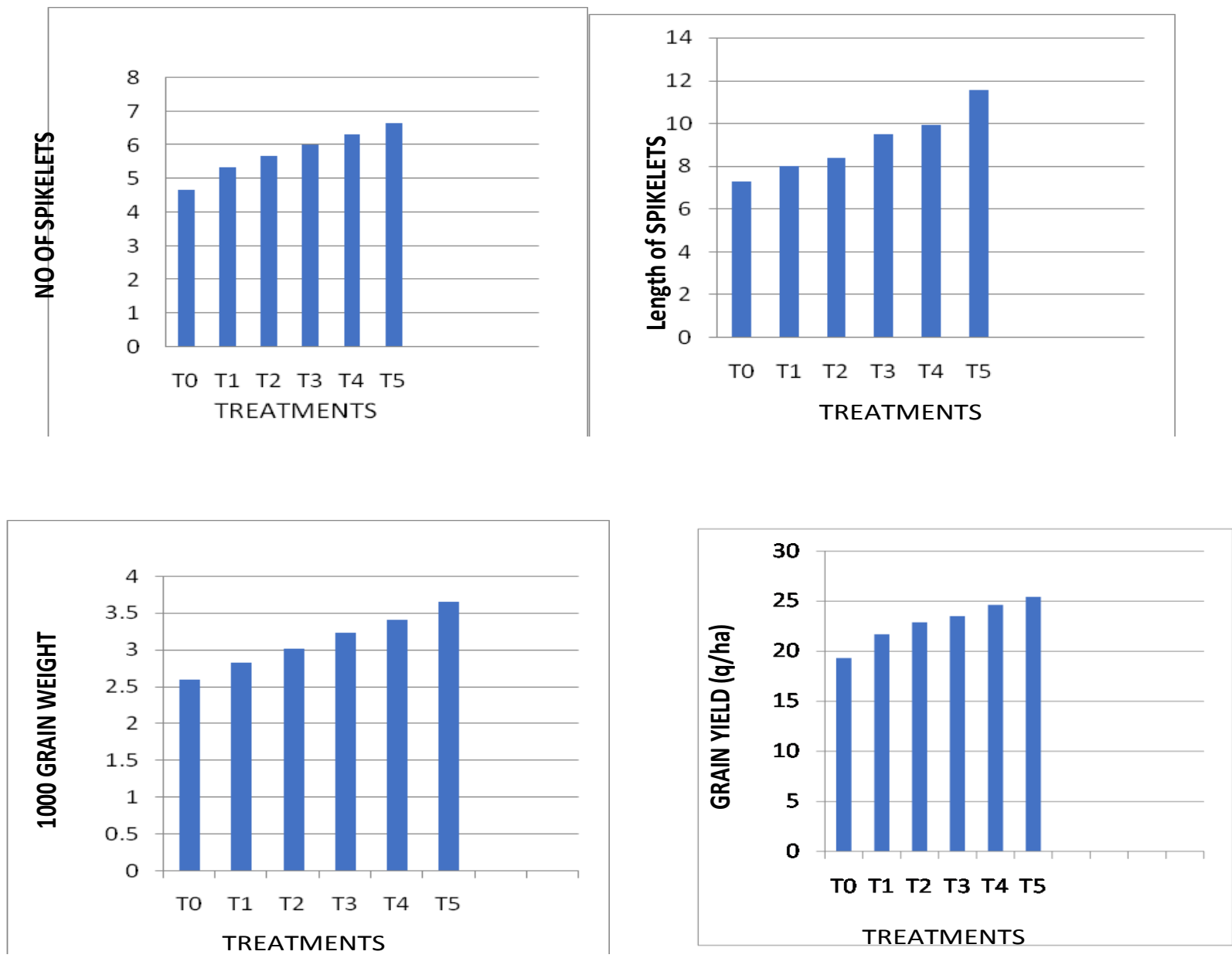
However, the present study was limited to lab conditions in case of Curvularia, therefore to substantiate the present result more trials are needed for 2-3 seasons in field conditions for further recommendations.

\section{References}

Annonymous. Annual Report (2013). All India Coordinated Small Millets Improvement Project. Project Coordinating Unit (Small millets), ICAR, GKVK, Bangalore. Pp. 33-39.

Edward Butler (1957). Rhizoctonia solani as a parasite of fungi. Mycologia 49 (3), 354-373.

Benoit M A and Mathur S B (1970). Identification of species of Curvularia on rice seed-Proceedings of International Seed Testing Association. 35: 99-119

IbrahimB. M and Naveen A. R (2008). The potential for using culture filtrate of Chroococcus minutes as fungicial agent against phytopathogenic Pythium sp. Egyptian journal of phycologyvol.9.

J. Tuite (1969). "Plant Pathological Methods: Fungi and Bacteria," Burgess Press, Minneapolis, 239 Pages.

Kulik,M.M (1995). The potential for using Cyanobacteria (blue - green algae) and algae in the biological control of plant pathogenetic bacteria and fungi. European Journal of Plant Pathology. 101: 585-599.
Malkhan Singh Gurjar, Shahid Ali, Masood Akhtar, Kangabam Suraj Singh (2012). Efficacy of plant extracts in plant disease management. 3:425-433

RangaswamiG, and Mahadevan, A (2004). Disease of crop plants in india $.4^{\text {th }}$ edition. Prentice Hall of India private Ltd. New Delhi. Pp. 177.

Rosenthal GA, (1991). The biochemical basis for the deleterious effects of Lcanavanine. Phytochemistry, 30: 10551058.

Sakamma S, Umesh K. B, Girish M. R, Ravi S.C., Satishkumar M, \& Veerabhadrappa B, (2018). Finger millet (Eleusine coracana L. Gaertn.) production system: Status, potential, constraints, and implications for improving small farmer's welfare. Journal of Agricultural Science, 10(1), $162-179$.

Schafer H, Wink M, (2009). Medicinally important secondary metabolites in recombinant microorganisms or plants: progress in alkaloid biosynthesis. Biotechnology Journal, 4(12): 16841703.

Tamuli P, Das J, Boruah P (2014). Antifungal Activity of Polygonum hydropiper and Solanum melongena against Plant Pathogenic Fungi. Plant Archives; $14: 15-17$.

Vincent, J.M (1947). Distortion of fungal hyphae in presence of certain inhibitors. Nature. 150: 850.

\section{How to cite this article:}

Sandra Saichandrababu Naidu and Sobita Simon. 2021. Effect of Micro Algae on Rhizoctonia solani and Botanicals on Curvularia spp. of Finger Millet (Eleusine coracana L.). Int.J.Curr.Microbiol.App.Sci. 10(02): 2313-2321. doi: https://doi.org/10.20546/ijcmas.2021.1002.275 